
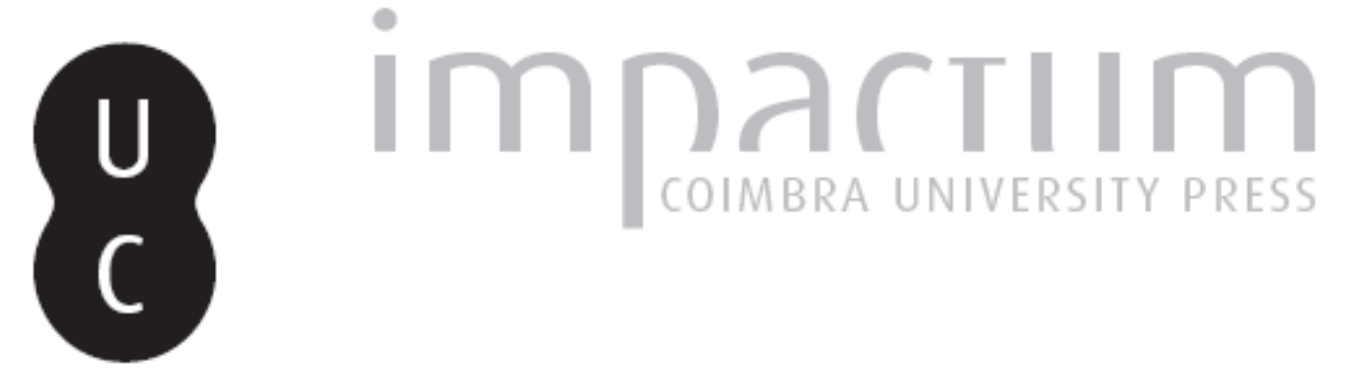

\title{
Diálogo da Igreja com a cultura
}

\section{Autor(es): $\quad$ Gomes, António Ferreira}

Publicado por: Imprensa da Universidade de Coimbra

URL persistente:

URl:http://hdl.handle.net/10316.2/45277

DOI:

DOI:https://doi.org/10.14195/2183-8925_8-1_17

Accessed : $\quad$ 26-Apr-2023 10:39:21

A navegação consulta e descarregamento dos títulos inseridos nas Bibliotecas Digitais UC Digitalis, UC Pombalina e UC Impactum, pressupõem a aceitação plena e sem reservas dos Termos e Condições de Uso destas Bibliotecas Digitais, disponíveis em https://digitalis.uc.pt/pt-pt/termos.

Conforme exposto nos referidos Termos e Condições de Uso, o descarregamento de títulos de acesso restrito requer uma licença válida de autorização devendo o utilizador aceder ao(s) documento(s) a partir de um endereço de IP da instituição detentora da supramencionada licença.

Ao utilizador é apenas permitido o descarregamento para uso pessoal, pelo que o emprego do(s) título(s) descarregado(s) para outro fim, designadamente comercial, carece de autorização do respetivo autor ou editor da obra.

Na medida em que todas as obras da UC Digitalis se encontram protegidas pelo Código do Direito de Autor e Direitos Conexos e demais legislação aplicável, toda a cópia, parcial ou total, deste documento, nos casos em que é legalmente admitida, deverá conter ou fazer-se acompanhar por este aviso.

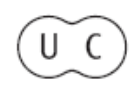


REVISTA DE HISTÓRIA DAS IDEIAS $\mathbf{8}$

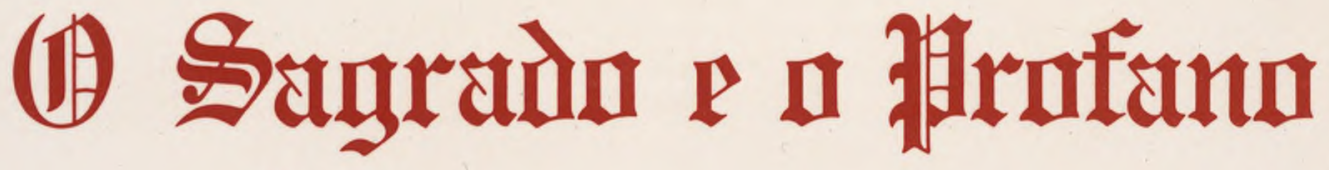 s.1. \\ HOMENAGEM A J. S. DA SILVA DIAS}

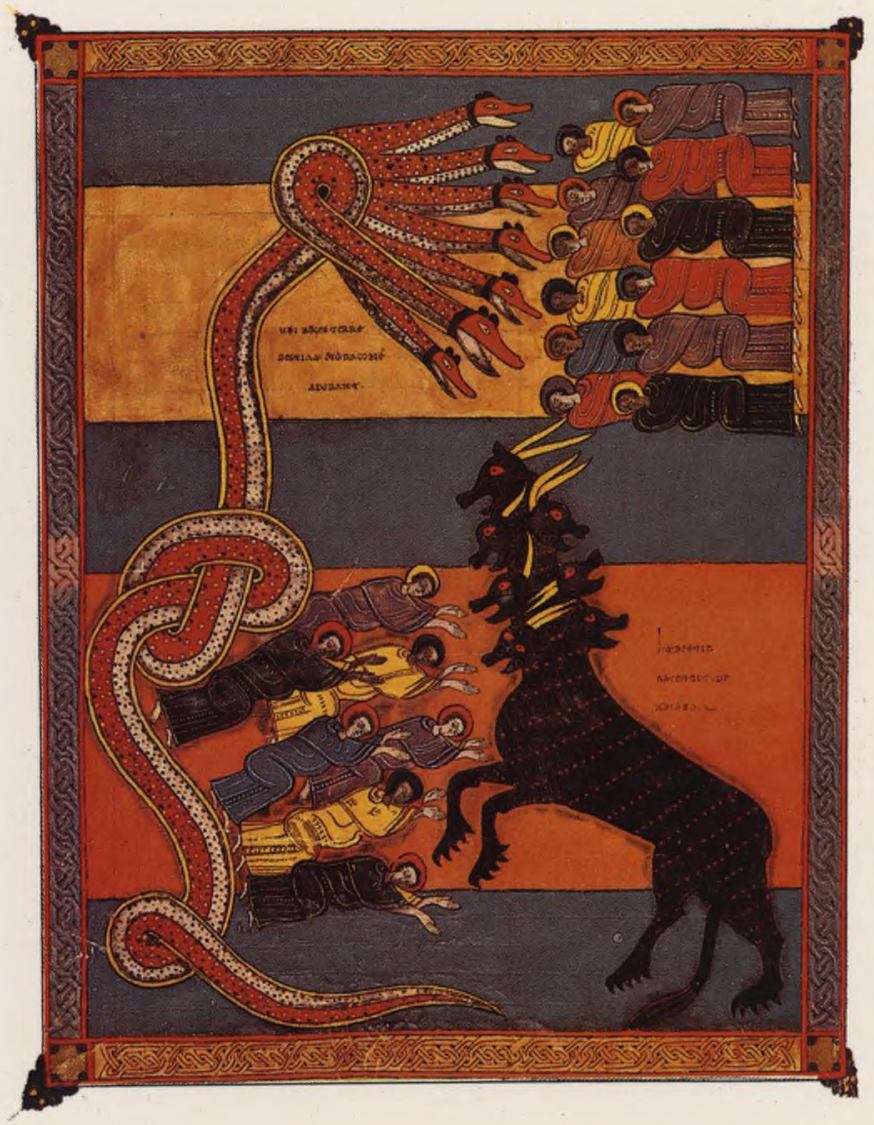

INSTITUTO DE HISTORIA E TEORIA DAS IDEIAS FACULDADE DE LETRAS 
D, ANTÓNIO FERREIRA GOMES *

\section{DIÁLOGO DA IGREJA COM A CULTURA**}

A criação e instituição do Conselho Pontifício para a Cultura, determinada por Sua Santidade o Papa João Paulo II em Maio de 1982, parece-nos ser uma das iniciativas de maior significado e alcance do Seu Pontificado e da qual podem resultar os melhores frutos para a Igreja. Poderá vir a ser um órgão permanente de comunicação da Igreja com a Cultura, isto é, com o Homem do nosso tempo mas no que ele tem de supra-temporal, com o Homem na consciência de si e da História.

\section{O Concilio e a Cultura}

O Concílio ao tratar da devida promoção da Cultura e seu progresso, sobretudo no capítulo II da Constituição Guadium et Spes, não poupa as expressões de valoração do progresso cultural, da contribuição necessária da Igreja para esse progresso e dos benefícios que dela podem resultar para a causa de Deus entre os homens do presente e do futuro.

Acentua-se sobretudo o carácter de novidade que deve aceitar-se e que haverá de moldar o contributo da Igreja para o progresso cultural. Fala-se expressamente de «uma nova idade da história humana», reconhece-se que «somos testemunhas hoje dum novo humanismo» e acentua-se, para os cristãos, «a responsabilidade para com os irmãos e diante da história».

* Bispo Resignatário do Porto.

** Este texto é tomado, com leves alterações, do livro em preparação Cartas ao Papa sobre alguns Problemas do nosso Tempo Eclesial. 
Concretiza-se mesmo um dos aspectos fundamentais do progresso cultural, que é sem dúvida crucial para a futura acção da Igreja que é a consciência e vontade de existencia sobre si e por sua conta do homem moderno: «no mundo inteiro progride de cada vez mais o sentido da autonomia».

Ao lado desta consideração do avanço da Cultura no mundo inteiro, vem naturalmente a recomendação do respeito pela cultura particular de cada povo. Mencionando esta dimensão, estamos a lembrar que o diálogo da Igreja com a Cultura se deve alargar ao seu diálogo com as várias culturas.

\section{Aculturação e Inculturação}

Esta consideração da pluralidade das culturas com que a Igreja se tem encontrado e continua a encontrar-se nas dimensões da história e da geografia levaria a considerar os problemas da aculturação e da inculturação (como se diz desde a Mensagem ao Povo Cristão do Sínodo de 1977).

Isto levar-nos-ia muito longe; e assim poderemos encerrar esta matéria com a recordação dum episódio ocorrido na aula conciliar com um Bispo chinês. Este bom Bispo, expulso da China e residindo na Europa, inscreveu-se para falar e falou longamente em defesa dos valores do seu povo (contra os comunistas) e alargou as suas considerações à valorização das culturas aborígenes, às tradições primitivas dos Povos, à revelação universal, aos semina Verbi, etc. Com tanto entusiasmo e tão longamente falou que o Cardeal Presidente - por sinal, se a memória me não atraiçoa, também ele de estirpe asiática (arménio) - acabou por interrompê-lo, dizendo-lhe: — Senhor Bispo, falou tão bem que já todos estamos convencidos; apesar disso teríamos gosto de continuar a ouvi-lo, mas o seu tempo acabou...

\section{Cultura ecuménica de hoje}

Com muito respeito pelas várias culturas particulares, devemos reconhecer que a cultura tende por si mesma ao universal. Podemos bem dizer que toda a cultura ou é já universal ou tende para sê-lo, sob pena de não ser cultura. Haverá de reconhecer-se que certas atitudes de veneração, diremos mesmo actos de culto para com particularismos aberrantes de cultura, quando passam de simples folclore, denunciam ou descrença na própria cultura universal ou sucedâneos da anti-cultura que grassa há bastante tempo nos vários ramos da cultura ocidental. 
Deixou escrito o Concílio (G. S., 54) : «Pelos meios (materiais) de cultura prepara-se pouco a pouco um tipo de civilização mais universal que faz avançar a unidade do género humano e a expressa». Esta unidade do género humano, que hoje se realiza e expressa pelos meios técnico-científicos, teve de começar pela exploração da geografia planetária e pela descoberta e encontro com as gentes isoladas e fechadas sobre si.

É na origem dessa missão histórico-transcendente de afrontar e devassar os oceanos e continentes atlântico, índico e pacífico que os portugueses, juntamente com os nossos irmãos espanhóis, estiveram ao serviço da Europa e da Fé cristã. Considerando as grandes migrações dos povos, que geralmente seguem a rota do sol, de Oriente para Ocidente, podíamos ver as grandes ondas migratórias euro-asiáticas, quase sempre terrestres, detidas por um tempo de séculos diante do Mar Tenebroso; e zarpando enfim contra as trevas no mistério geográfico e no futuro histórico. Isto dá-se no princípio da Renascença, participa da mesma força expansiva e conquistadora em todos os domínios e dá ou confirma no homem renascente, em nome da geografia e do saber empírico, uma outra imagem do universal, que substitui e empana o brilho das ideias puras, o conceito mediévico do universal metafísico.

\section{Nominalismo, voluntarismo e renascimento}

Com o Renascimento, de dominante pagã, nasce também o Protestantismo. Ora o Concílio em que participamos foi acusado, pelo cisma econiano principalmente, de ter introduzido o Protestantismo na Igreja ou de ter protestantizado a Igreja. É grave confundir o fim da Contra-Reforma com a protestantização da Igreja.

Como não se trata tanto de juízos de valor como de reacções de sentimento, posso testemunhar pessoalmente. Ao deambular pelos espaços da aula conciliar, muitas vezes pensei e algumas vezes o confidenciei aos amigos: - Dizem que aqui, em S. Pedro, só entram agora os bispos e os herejes. É certo que vemos aqui ao lado anglicanos, luteranos, calvinistas, etc. Mas, na verdade, atendendo ao ambiente dos nossos estudos e deliberações, parece que estamos mais perto e mais irmanados com as vítimas de Calvino e Lutero ou da Inquisição do que com os juízes do tribunal da fé ou com os heresiarcas contrários.

Defendendo a liberdade religiosa, a obrigação de seguir a própria consciência, a necessidade que a profissão do Evangelho resulte na vida mesmo social e política, etc., estamos mais 
perto dum Miguel Servet, dos anabaptistas, dum frei Valentim da Luz, do que de quem os exterminou «por amor de Deus»...

Do lado protestante «Lutero foi comumente considerado como o fundador duma nova Igreja» - reconhece a Comissão mista católico-luterana, na sua Declaração de 6 de Maio de 1983, por ocasião do quinto centenário do nascimento de Martinho Lutero.

Aí está o seu mal: rompeu as barragens e depois quis deter as águas, mesmo naquilo que a história foi mostrando ser seu domínio legítimo. E, juntamente com isto, ter deixado misturar a fé com o nacionalismo ou até de confiar os seus destinos às estruturas estatais, o que, antes de ser anti-teológico, é anti-cultural. Na verdade, do lado protestante, tido como «herói da fé», a essa glorificação juntou-se frequentemente a sua exaltação como «herói nacional»; «por outro lado, certas fraquezas da organização das Igrejas protestantes tornaram-se manifestas, em particular a sua integração nas estruturas do Estado» - confessa ainda a mesma Comissão católico-luterana.

Prescindindo de quaisquer qualificações teológicas, devemos reconhecer que nacionalismo e estatalismo são na sua essência e tendências anti-culturais, pois que toda a cultura ou é universal ou tende para o universalismo e o Estado deve ser um fenómeno de Cultura, mas não vice-versa.

\section{Cultura de «curva a cerviz»?}

Nesta «nova idade da história humana» em que estamos situados, dentro deste «novo humanismo» que devemos viver, é bem tempo de acabar a velha fórmula de «conversão»: «Curva a cerviz, fero Sicambro, queima o que adoraste e adora o que queimaste».

Certamente ninguém pensará hoje em tais imposições feitas expressa e claramente em matérias religiosas. Mas, além de pressões e objecções, sobretudo de estruturas políticas, que levam o mesmo caminho, que isto seja a favor de qualquer teísmo ou do ateísmo, devemos no mundo católico evitar todas as reminiscências e equivalências em matéria de Cultura.

Uma das formas mais subtis, dissimuladas e actuantes destas reminiscências e equivalentes está em partir do pressuposto, geralmente não afirmado e talvez não pressentido, de que tudo quanto se passou nos domínios da Cultura durante séculos, é como se não tivesse existido e como tal se pudesse simplesmente postergar.

Sabemos que a Reforma católica que marca a Era moderna, depois da grande crise que afectou a Igreja no fim da Idade 


\section{Diálogo da Igreja com a Cultura}

Média, foi vista por muitos apenas como contra-Reforma; e essa visão negativista ainda não desapareceu totalmente de muitas mentalidades. Para dar a estes problemas a sua devida dimensão e horizonte histórico, podíamos começar por dizer que o movimento que podíamos chamar de adolescência e de independentização para com a Igreja começou muito antes das Reformas protestante e católica. Apetecia quase tomar a frase da Gaudium et Spes sobre a situação actual — «no mundo inteiro progride de cada vez mais o sentido da autonomia» - e transliterá-lo da seguinte maneira: na história cultural inteira, desde o fim da Meia-Idade, progride de cada vez mais o sentido da autonomia...

Poderíamos começar por advertir que na grande Escolástica se funda e cresce o conceito de autonomia, de harmonia com a tese de Tifelich na sua Teologia da Cultura de que a Cultura é ao mesmo tempo autonomia e teonomia.

Mas, deixando o grande plano teocêntrico da pessoa humana como aquilo que é propter se quaesitum in universo, consideremos o avanço da autonomia como parte do progresso do antropocentrismo (legítimo ou ilegítimo). Este progresso antropológico, legítimo no sentido da encarnação do Verbo de Deus, ilegítimo no sentido talvez do velho filósofo grego de que o homem é por si a medida de todas as coisas (pántôn chremátôn metron anthropos), tal progresso foi-se definindo a partir do nominalismo parisiense como uma espécie de transição do espaço da inteligência para o espaço da vontade e portanto do poder. Antes avançava-se da ciência para a consciência; agora, na era moderna, é da ciência para a potência que se quer progredir. Saber é poder, vai-se repetindo cada vez mais desde Descartes. O próprio matematismo epistemológico cartesiano ou o geometrismo spinozista - pensar e argumentar more geometrico — são tentações de construtivismo da verdade e depois dos valores.

A par disso e com isso, como causa e efeito, vai crescendo o interesse pelo concreto, pelo conhecimento técnico, pelo empirismo do saber, pelo experimentalismo e tecnologismo. Este nominalismo, espécie de cansaço da inteligência pura a favor da inteligência manual e construtivista levará finalmente ao construtivismo social, traduzido no conhecido epifonema: a filosofia já se ocupou demasiado de compreender o mundo, o que é preciso é transformá-lo. Os gregos já diziam que o homem é inteligente porque tem mãos; mas não se esqueciam que deve também ter cabeça.

Agora joga-se entre o andar sobre a cabeça do racionalismo hegeliano' ou repor o homem a andar sobre os seus pés; mas este andar sobre os pés no materialismo marxiano, dum 
homem todo feito «universal concreto», é tanto ou mais idealista do que a ideia pura de Hegel. Este nominalismo e voluntarismo metafísicos, esta opção pela vontade contra a inteligência, pelo querer contra o ser, pela potência contra a consciência, este progresso que também se poderia ver como regresso do homo sapiens ao homo faber, tais fenómenos e outros da mesma ordem são sem dúvida deformações da verdade global, desvios do recto caminho do pensar e agir. Mas falar de deformações significa que há uma forma, falar de desvios significa que há uma via direita; importa não perder a forma por causa das deformações, nem recusar a via por medo dos desvios.

É de evidente necessidade examinar se tal acidente não terá acontecido e em que medida terá acontecido: se, conforme a conhecida imagem, não se terá por vezes deitado fora a criança com a água do banho. Deverá decerto reconhecer-se que em certas escolas e em vasta literatura católicas, geralmente em nome dum neo-tomismo tresnoitado, se condenava às gemonias todo o pensamento e cultura pós-medievais. Dizia-se mesmo às vezes, de forma sumária e contemptiva, que toda a história da filosofia moderna e contemporânea era o cemitério de todos os erros e disparates que se disseram depois de S. Tomás.

Mas a coisa chegou mesmo ao mais alto da escala doutoral. Assim, por exemplo, um teólogo como Karl Rahner que tem consumido a sua vida a responder às interpelações que a Cultura contemporânea põe, expressa ou implicitamente, à Igreja e a inserir as doutrinas filosófico-teológicas actuais na continuidade das exigências da especulação ontológica de sempre, da qual Tomás de Aquino é um dos mais altos expoentes, Rahner tem sido reprovado como não-tomista, como infectado do espírito do tempo e infiltrado pelo idealismo filosófico, e até de, por ocasião do Concílio (antes de nele ser admitido, pelo Papa, como perito oficial) poder tender a ofuscar o sol romano com os nevoeiros germânicos.

Não menos significativo é que o cisma econiano (muitíssimo mais largo que o seu núcleo de Ecône), começando por acusar o Concílio de introduzir o protestantismo na Igreja, logo passa a acusá-lo de igual pecado a favor da Revolução francesa e da sua «abominável trilogia» de Liberdade, Igualdade e Fraternidade, e vem a terminar na denúncia do Concílio como adoptando o modernismo, o que para Ecône significa aceitar qualquer espécie de modernidade. Quer dizer que para o integrisme eclesio-teológico a Igreja deve considerar que na história cultural do mundo se abriu um enorme vazio ou Chaos magnum duns cinco séculos durante os quais não houve senão erros e perversões. 
Acusar o Concílio de ter tido e expressado uma visão contrária significa uma grande intuição a respeito da sua atitude de fundo para com o integrismo e quanto ao discernimento a usar com o bloco imenso e multiforme da modernidade ou do mundo que nos foi dado viver e que devemos viver como dádiva e como tarefa (Gabe und Aufgabe, no dizer alemão).

\section{A cultura hodierna e os «mestres da suspeição»}

O diálogo da Igreja com a Cultura tem de pôr o homo ecclesiasticus em conversação de ideias com as culturas, assim de cada povo ou etnia como igualmente mas com maior alcance e interesse também de cada século ou idade civilizacional.

Como hoje se pode bem falar duma cultura ecuménica, é com essa que o homem da Igreja tem principalmente de conversar. Esta conversação da Igreja com a cultura ocidental, hoje virtual ou actualmente ecuménica, não pode ignorar que do outro lado está o homem que, depois do nominalismo "parisiense», ouviu Descartes, Spinosa e Galileu, que, depois do empirismo «inglês», ouviu Kant e Hegel e que chegou ao «século das Luzes» conduzido pelo deísmo racionalista da Aufklàrung ou pelo anti-catolicismo mais ou menos ateísta da Enciclopédia.

Esgotados os recursos das ciências naturais e físico-químicas contra a tradição cristã ou contra Deus e o seu Cristo, pela «ilustração» do século XVIII, a marcha do pensamento humano não pode parar e por isso o século XIX, ao lado do romantismo que é o último termo do voluntarismo substituindo a inteligência e vontade pelo sentimento, descobre e cria as "ciências humanas», que devem ser e melhor se chamariam ciências do espírito, a saber, principalmente a antropologia cultural, a sociologia e a psicologia. Mas este belo passo em frente, do qual muito se podia e pode ainda esperar, é logo estorvado e inflectido pelos legítimos filhos da Aufklàrung passada.

Nietzsche chama a si a cultura grega e oriental para criar um super-cristianismo de substituição, para opor o seu super-homem ao sobrenatural cristão, para pôr o seu Zaratustra a cantar um contra-Evangelho, às vezes com as próprias imagens, perspectivas e até mesmo semiótica e linguística do Evangelho. Quer dizer que a antropologia cultural, está abrindo o caminho do Mistério absoluto que em última análise chamamos Deus.

Marx, ao lado da sua actividade de revolucionário teórico, mais ou menos virulenta conforme os tempos e as circunstâncias, considera que o homem está ainda por fazer, tem 
vivido a sua pré-história. Vai agora realizar-se a historia do homem, fazendo com que cada indivíduo seja portador da humanidade, isto é, se identifique com o seu próprio género ou com a espécie humana ou realizando em si o «universal concreto». Isto, que chamaram dialéctica marxista, é evidentemente metafísica, metafísica má e impossível sem dúvida.

Para realizar este impossível metafísico (e portanto também dialéctico) do indivíduo singular como universal e universal concreto, Marx recorre a um moralismo transcendente, não menos metafísico e igualmente erróneo, moralismo que, através de Hegel, recebera de Kant e da sua «razão prática» (isto é, a vontade) a postular e reconstruir tudo quanto a «razão pura» destruirá, moralismo e voluntarismo que o próprio Kant, pelo seu pietismo de formação, recebera da doutrina da justifícação de Lutero, como este teria encontrado no nominalismo a razão filosófica da sua teologia da fides sola e gratia sola.

Concretizando este moralismo metafísico, Marx propõe-se destruir o capital e a propriedade privada, capital e propriedade que são o próprio pecado, são a origem de todos os males e de todo o pecado: só despojado de tudo o indivíduo pode identificar-se com a sua espécie, pode realizar o universal concreto. Em linguagem de catecismo, abolido o capital estão suprimidos os sete pecados capitais; e, automaticamente decerto, implantadas as sete virtudes contrárias...

De Freud se pensa que pôs em curso o materialismo prático e o pansexualismo dos costumes. Sem querer absolvê-lo de certas culpas originais no que a baixa literatura esparrinhou por toda a parte, devemos reconhecer que, como cientista, a dinâmica do seu sistema, face às escolas de psiquiatria então vigentes que se ficavam pelo organicismo e fisiologismo, isto é, pela redução ao estudo das funções somáticas, ele dá às ciências psicológicas a sua própria autonomia científica, restitui pois à psyché o seu lugar próprio no composto humano.

A psicanálise pode ser bem ou mal conduzida, correndo o risco de julgar o normal pelo anormal, mas de toda a maneira procura responder ao preceito que todo o homem, naturalmente mais o espiritual e religioso, reconhece em si: nosce teipsum!

Também a universalização do instinto de amor, ao lado e na alternativa do instinto da morte, a explicação da moralidade inter-humana e da sociedade pela sublimação dos instintos, o sentido da expiação duma falta primitiva (a morte do pai) na origem das sociedades humanas, etc., mereciam largas considerações que nem todas seriam negativas, qualquer que seja o juízo de valor global sobre o homem e a sua ciência...

Três homens, três ciências humanas - antropologia cultural, sociologia e psicologia — que podem e deviam chamar-se 
mais exactamente ciencias do espírito. E devemos reconhecer que também eles, esses três "maîtres du soupçon», como justamente lhes chamou Paul Ricoeur, se movam como que clandestinamente e a contra-gosto no terreno e aos niveis que sempre foram os da Igreja, nível cultural, metafísico e para-teológico. Mestres da suspeição, lançam dúvidas e objecções contra a tradição cristã como vêem à sua volta (a ambiência mental dos mestres era protestante) e apontam como ideal algo de novo, mais humano, nobre e eficaz; mas efectivamente não conseguem desprender-se das raízes cristãs, embora laicizadas, nem atingir ideais que superem o Evangelho, embora ultrapassem a prática dos cristãos comuns. Mestres da suspeição, tornaram-se mestres, donos e senhores da alma contemporânea: foram e ainda o são, porque, embora um pouco embaciados no seu brilho e sedução, ainda não foram substituídos no seu magistério e domínio. É pois através destes ou através dos seus epígonos que tem de dar-se o diálogo da Igreja com a Cultura.

Falar apenas com aqueles que acatam a doutrina e disciplina eclesiásticas é a Igreja a falar consigo mesma, é um monólogo de fala-só. Por outro lado, dialogar não é aceitar simplesmente a opinião ou posições do parceiro; mas tão pouco pode ser um «curva a cerviz». Mesmo nos sistemas mais aberrantes há geralmente mais verdades do que erros: o mal é em geral do sistema, não da substância do que se pensa.

Mas a cultura nas suas fontes passa normalmente por sistemas. E os sistemas dos «mestres da supeição», bem como os dos seus epígonos não escapam à regra: são falsos sistemas, assentes sobre um fundo de civilização cristã e para cristãos, aspirando talvez a um hiper-cristianismo surrealista.

\section{Encarnação cultural de Cristo}

«A encarnação humana de Cristo foi também uma encarnação cultural» - disse o Papa João Paulo II para os intelectuais em Coimbra.

Jesus de Nazaré nasceu e criou-se na cultura aramaica, que pelo seu núcleo era uma cultura israelítica dentro das culturas semitas; não seria isso só que o Papa desejava focar ao considerar a encarnação cultural de Cristo. Atrevo-me a pensar que apontava para alguma coisa como aquilo que tentei esboçar no que levo escrito.

Aos que se perderam pelos caminhos dos maîtres du soupçon, caminhos de humanismo ateu, haveria que dizer, não que parem ou recuem nos seus caminhos, mas que avancem mais e mais nas sendas do humanismo, que procurem sondar até ao 
fundo os mistérios do homem e que, se bem lograrem o fim da sua caminhada, encontrarão finalmente o Mistério absoluto e pessoal a que chamamos Deus e que é, segundo a palavra de Agostinho, interior intimo meo, superior summo meo.

A encarnação cultural de Cristo tem de repetir-se na Igreja, de idade em idade, de século a século. No século presente essa encarnação cultural da Igreja não pode deixar de ser afectada pelos acidentes da cultura neste tempo. Há que reconhecer que chegamos hoje a uma crise da cultura que só se pode definir na história como período de anti-cultura.

Nas letras e nas ciências, na poesia, na música e no teatro, nas artes plásticas e na arquitectura, na sociologia, na filosofia e na teologia, reconhece-se um estado de crise, que muitos abertamente confessam como estado de anti-cultura e não poucos cultivam francamente como tal, com aceitação e proveito material bem patentes. Como justificação avança-se geralmente que nos vários domínios todos os recursos estão esgotados, todas as experiências foram feitas, todos os caminhos foram encetados e se revelaram «caminhos de floresta», caminhos que morrem no mato e obrigam a romper passo novo. E assim culturalmente se vai agindo ou nos vamos agitando, à espera de novas formas de cultura.

Claro está que a crise cultural generalizada não pode deixar de reflectir-se na Sociedade e no Estado, quer nacional, quer intemacionalmente. Fala-se duma crise geral de civilização, que se estão esgotando os meios e institutos civilizacionais, que os costumes particulares e públicos não respondem ao estado de liberdade de que felizmente nos dotamos. Assim, por exemplo, o Estado-Providência, generosa criação do nosso tempo, está em falência por toda a parte, falência financeira e económica resultante da falta de honestidade do cidadão para com esse Estado; mas não se vê maneira de corrigir ou reprimir os costumes que a tal falência conduzem. Como dizia o historiador clássico, não podemos já suportar os nossos males nem os seus remédios.

Evidentemente, se a humanidade se não destruir completamente a si mesma, deste ocaso nascerão novas auroras. E o novo dia muito vai esperar da Igreja, muito vai pedir ao espírito, que finalmente será o Espírito Santo.

Como bom prenúncio, já disse e permito-me repetir, que as «ciências humanas» são e devem sempre ser consideradas ciências do Homem pessoal e social, portanto ciências do espírito. E estas ciências vieram a procurar preencher o vazio do humano na cultura e na vida, deixado pela negação do divino autêntico na teoria e na prática das «Luzes» do século XVIII. 
À falta dos conceitos da auto-comunicação de Deus ao homem, da graça santificante do sobrenatural, responde o ideal nietzschiano do super-homem, um hiper-cristianismo de contradição, um contra-Evangelho de substituição.

À falta do sentido comunitário, da solidariedade inter-humana e institucional, da Agápe cristã devida ao individualismo decimonónico, aparecem os comunismos vários, a metafísica marxiana do homem-género e do universal concreto.

À falta duma «teologia do corpo», do «sentido do dom»e do carácter «esponsal» próprios do corpo humano - como o Papa João Paulo II ensinou na sua catequese - ao falso e obsessivo pudorismo, ao amartiocentrismo sexual, sucede a universal Libido freudiana, o pan-sexualismo com a sua sublimação individual e social, negando o pecado e o espírito.

Super-humanidade, Sociedade metafisicamente perfeita, Amor libidinal, são os ídolos do nosso tempo. Mas é bem preciso reconhecer que por detrás dos ídolos está sempre, mais ou menos longínquo, mais ou menos ignoto ou anónimo o próprio Deus. Assim foi sempre na idolatria pagã, assim é na idolatria post-cristã deste tempo.

\section{Cultura e culto}

O homem não pode ser nem existir sem cultura: também não pode ser nem existir sem culto. Culto e cultura correspondem-.se, interligam-se, actuam reciprocamente e desenvolvem-se a par. A cada cultura o seu culto: a cada culto a sua cultura. ídolos.

Cultura e culto de Deus: no próprio Deus ou nos Seus

Pôr em relevo esta relação entre culto e cultura leva-nos naturalmente a uma consideração final das relações entre a doutrina e culto de Deus único e o culto e doutrina das idolatrias multiformes. Sabemos dos esforços feitos através dos tempos para manter o puro monoteísmo e como esses esforços derivaram quer para um quer para outro lado.

No Israel antigo conhece-se o zelo sacerdotal em combater o culto dos ídolos, chegando para isso à destruição das memórias históricas mais compreensíveis, como a pedra do sonho de Jacob ou gilgal elevado por Josué em memória da passagem do Jordão. A mesma defesa do monoteísmo se atribui ainda hoje, como missão histórica, o judaísmo ortodoxo. Sabe-se como tal esforço foi em grande parte baldado na vida pública de Israel, quer pela introdução dos ídolos circunvizinhos quer pela transformação do próprio templo em ídolo. Hoje a vertente 
desse zelo monoteísta será mais a contrária: a queda no deísmo, no racionalismo e finalmente no ateísmo.

$\mathrm{Na}$ pregação e culto do Islam, corn a recusa da representação da figura humana ou animal para manter puro o culto de Alah a historia não será muito diferente, embora com outras aparências.

Também na história cristã a iconoclastia oriental ou protestante não terá deixado de ocasionar o avanço no sentido do racionalismo, do deísmo, do fideísmo, pietismo e moralismo, finalmente do ateísmo.

No catolicismo actual deve reconhecer-se igualmente a dificuldade de manter o equilíbrio entre a fé e culto do monoteísmo trinitário e várias tendências da religiosidade popular.

A actual desafeição pelo culto dos santos e suas representações plásticas pode sem dúvida invocar várias razões, no caso de se assumir conscientemente e portanto de passar do simples reconhecimento de mera mutação temporal de mentalidade religiosa ou geralmente cultural. Há muito vem sendo denunciada, mesmo por muitos «espirituais», essa «barricada de santos» que fazem pantalha opaca contra Deus e o seu Cristo. Que há em certo culto das imagens, nas promessas e seu pensamento, em certo comércio do ut des, etc., vestígios evidentes de idolatria, que se torna clara mesmo entre nós mas muito mais nas Américas onde os nomes dos santos e as várias invocações da Virgem recobrem os deuses e deusas dos cultos africanos.

Mas ao procurar depurar o cristianismo destas excrescências da religiosidade natural (natural, humana e portanto infindamente renascente) não se deverá cair, sob a invocação da racionalidade, no puro racionalismo, no deísmo e no ateísmo. Daí nascerão os novos ídolos, que por vezes se revelam não menos devoradores de homens do que qualquer velho Moloch ou Baal...

Para considerar em concreto as relações entre a teologia e a liturgia do monoteísmo trinitário por um lado e a religiosidade popular cristã, pelo outro, haveria que considerar os vários estratos ou níveis culturais de cada povo ou comunidade humana, porque na verdade nem todos os que vivem no mesmo tempo são contemporâneos. Por isso é que a pastoral de massas, se pode ocasionalmente ter algum interesse, deve habitualmente ceder lugar à pastoral da pessoa ou do grupo. $\mathrm{O}$ modelo é sempre o Evangelho, em que turba, discipulado e apostolado têm níveis diferentes, recebem instrução correspondente ao seu nível e tornam-se objecto de exigências muito diversas. 


\section{Cultura e mass media}

A pastoral de massas leva-nos naturalmente à consideração do problema dos mass media na pastoral, designadamente da radiodifusão e da televisão. Se já outrora quem pregava devia estar mais atento aos que não estavam ali na igreja ou não afinavam pelo tom comum da assembleia, hoje que a palavra e a acção litúrgica são lançadas super tecta e penetram em toda a parte, quanto cuidado não deverá haver para que se não viole na difusão da doutrina e moral religiosas aquele princípio primeiro da farmacopeia e terapêutica - ne quid mali faciat!

Talvez devesse começar por perguntar-se se a liturgia sacramental e sobretudo eucarística, que deve desenvolver-se num ambiente sagrado em ritmo de oração, recolhimento, fé convivida e corpo místico, estará bem derramada pelas ruas, nos cafés e tabernas, no meio do barulho e de espectáculos profanos ou mais que profanos. Sempre foi difícil dar bem o sagrado em espectáculo, sempre o sublime convizinhou com o ridículo; mas agora, com o «direito» dos media... direito a pôr o mais íntimo, pessoal e sagrado em espectáculo!

Pode dizer-se que o diálogo da Igreja com a Cultura exige tudo isto; mas, admitindo mesmo que aí ainda seja terreno de cultura, não podemos esquecer que o diálogo da Igreja é, histórica e primacialmente, com a alta Cultura, de que estes meios e espectáculos são apenas reflexos, decerto muito longínquos, se mesmo ainda são culturais.

E o diálogo com a alta Cultura vai, de degrau em degrau, encontrar-se com os «mestres da suspeição», os quais feitos mestres, donos e senhores da Cultura ou da alma contemporânea, agora já um pouco deslustrados e talvez postos eles próprios um pouco em certa suspeição, continuam a sê-lo - eles ou seus epígonos - porque ainda não foram substituídos. Nada e ninguém acabou enquanto não foi substituído... 